\title{
Enlightenments from High School Online English Class in China During Pandemic
}

\author{
Jiaming Chen
}

\author{
English Language Centre, Shantou University \\ *Corresponding author. Email: jmchen@stu.edu.cn
}

\begin{abstract}
Thanks to COVID-19, renovations have been witnessed in English classes in Chinese public schools because all the off-line classes were forced to be transferred online. However, teaching distantly was a new attempt for most teachers in traditional schools, especially in developing cities. Thus, I have doubts about the learning outcomes of the 'national distant class'. Moreover, this research also explores what challenges and adaptions teachers had made to achieve their tentative teaching objectives. This research was conducted in public high schools in Nanchang, Jiangxi Province. Six English teachers shared their experience of teaching remotely. The result shows that students' learning outcomes are not ideal. This article reveals the factors that contribute to students' underperformance in distant learning from both teachers' and students' perspectives. The thesis ends up with some suggestions which inspire English teachers working in the frontline to enhance their online teaching quality under the Chinese educational context.
\end{abstract}

Keywords: Digital learning, Digital teaching, Teacher's development, In- Pandemic English Class, Chinese high school

\section{INTRODUCTION}

The Covid-19 outbreak required all Chinese citizens to stay at home to prevent the spread of the virus. Therefore, teachers and students had to work from home which bred different digital platforms to physically move classes online. This is the very first time that teachers and students in the whole nation work online. Many studies show that digital learning can contribute to a better learning outcome by increasing students' learning motivation and interactions in class. Moreover, more input and output can be achieved with the help of online tools [10]. Unexpectedly, since high schools reopened from May, I heard lots of complaints about online teaching from parents and teachers. I wonder what factors lead to the gaps between theories and practice. This research is conducted to explore the reason why online teaching can be so challenging for teachers and students.

\section{DISTANT-LEARNING IN CHINESE EFL CLASS}

Kaufman and Nipper claimed that three generations were generated from distance learning. The first generation is relatively less interactive because a single digital tool was applied, such as educational-purposed TV channel or radio FM [8] [11]. It is characterized by effective instruction for large groups of students. The second generation was optimized by adding a third person to promote communication among students in class by using multi-media tools such as printings and broadcasting. In terms of the third generation, mutual way communication is achieved by internet tools which facilitate realizing a more equal and more efficient communication between teachers and remote students, remote students, and remote students [1]. In traditional Chinese English classes, senior high school teachers in public schools were still in the second phase. During the epidemic, part of students in Jiangxi Province uses Ganjiaoyun Channel, a pre-recoded video-based TV channel, which matches the first generation.

\subsection{Factors That Can Affect Curriculum Implementation}

Wang summarized that the main factors can be divided into two branches - external factors, which includes testing, teacher training, textbooks, and resource support; And internal factors, which contains teachers' beliefs and decision-making in making innovation, teachers' attitudes towards innovation and 
teachers' understanding and ownership of innovation [14].

\subsubsection{External factors}

Apart from tests and textbooks which were not influenced by the pandemic, teacher training seems to play a more important role. Studies have shown that pre-service teachers are not able to get adequate Information and communication technology (ICTs) training in normal universities. Similarly, in China, pre-service teachers tended to gain more pedagogical knowledge and off-line teaching experience before service, but very little input about using educational technology [5].

\subsubsection{Internal Factors}

Teaching belief is always underpinned in teachers teaching style, which plays the role of the nature teacher's instruction in the class [7]. Teaching belief can be adjustable based on student's needs, students' behavior, and class reality; however, the changes and adjustments are all based on teachers' initial core beliefs. Moreover, the shape of teaching belief is very likely to connect with teachers' pre-service experience. Other factors like teachers' personality, exposure to innovative thoughts and curriculum, school type which in-service teachers are working for, also are regarded an influential in developing teachers' beliefs [14].

Besides teachers' belief, teachers' ownership of innovations plays an important role in technology application in English class. Some Chinese researchers found out that more than $90 \%$ of teachers have positive attitude towards using digital tools in class. $81 \%$ of teachers tried to teach themselves in using computers in class, $71 \%$ of teachers believe they need more instructions and trainings to enable them to use education technology more flexibly [13].

\subsection{Mutual effects between the implementation of curriculum and distant learning}

\subsubsection{Distant Learning Has Changed the Paradigm of Curriculum Implication}

Because of the features of digital learning, the paradigm of learning theories has been transferred from behaviorism to constructivism [3]. Teachers who believe in learning behaviourism compare teaching to fill up knowledge into an empty bottle - their target student, hence students can gain passive knowledge from teacher- centred classes. Therefore, behaviourism can bring external performance to students. However, constructivism in education emphasises the process of building the knowledge net by learners their own instead of being inducted by teachers. Knowledge can be constructed with teachers' effective guide and shared social endeavours [6]. E-learning can effectively provide students with authentic materials and cultivate students' language competence. However, organizing collaborative projects and proceeding learning procedures are more time-consuming than traditional learning [3].

\subsubsection{Barriers in Distance Teaching for teachers}

Location of schools and access to technology prevent some teachers from innovating teaching with digital teaching. Because of the location limit, the resources teaching equipment, and training programs teachers can reach are varied, which contributes to the difficulties for teachers in less developed cities [12].

Higher level of workload, inadequate ability, pressure from parents can cause teachers' burnout [16]. Maslach et al. refer to burnout as emotional exhaustion, reduced personal accomplishment, and depersonalization, what is more, she gives a concrete description of burnout experience. However, these factors were brought up by teachers who are trying to reach out to new technologies in their class [9].

\subsubsection{Barriers in Distance Learning for Students}

Scholars point out that distance learning can decrease students' learning motivation for the following reasons: technology problems, shortage of communication and interactions, interruptions from daily life [4].

$\mathrm{Hu}$ found out in his research that computers and electronic devices can be very distractive for most of Chinese students, thus the outcome of teaching can be undesirable [6].

\section{RESEARCH DESIGN}

\subsection{Choice of sample}

6 participants were invited to share their own experiences. They are from a different working background. Participants' age ranged from early 20 to 50 , they are working in schools of different levels. 
Table 1 Information About the Participants

\begin{tabular}{|c|c|c|c|c|c|c|}
\hline $\begin{array}{c}\text { Particip } \\
\text { ants }\end{array}$ & Age & Gender & $\begin{array}{c}\text { Name of } \\
\text { Institution }\end{array}$ & $\begin{array}{c}\text { Years of } \\
\text { Teaching }\end{array}$ & $\begin{array}{c}\text { Educational } \\
\text { Background }\end{array}$ & $\begin{array}{c}\text { Students' } \\
\text { Information }\end{array}$ \\
\hline A & 50 & female & T1 & 20 years & $\begin{array}{c}\text { MA English } \\
\text { Education }\end{array}$ & $\begin{array}{c}\text { Grade 3top- } \\
\text { student class } \\
\text { Grade 3 Parallel } \\
\text { class }\end{array}$ \\
\hline B & 40 & female & T2 & 16 years & $\begin{array}{c}\text { MA English } \\
\text { Education }\end{array}$ & $\begin{array}{c}\text { Grade 1 top } \\
\text { student class } \\
\text { Grade 1 Parallel } \\
\text { class }\end{array}$ \\
\hline C & 38 & Male & T3 & 18 years & $\begin{array}{c}\text { MA English } \\
\text { Education }\end{array}$ & $\begin{array}{c}\text { Grade 2 Parallel } \\
\text { class }\end{array}$ \\
\hline D & 30 & female & T4 & 7 years & $\begin{array}{c}\text { MA English } \\
\text { Education }\end{array}$ & $\begin{array}{c}\text { Grade 2top- } \\
\text { student class }\end{array}$ \\
\hline E & 31 & female & T5 & 7 years & $\begin{array}{c}\text { BA English } \\
\text { Education }\end{array}$ & $\begin{array}{c}\text { Grade 2 top- } \\
\text { student class } \\
\text { Grade 2 Parallel } \\
\text { class t }\end{array}$ \\
\hline F & 24 & female & T6 & 1 year & $\begin{array}{c}\text { BA English } \\
\text { Education }\end{array}$ & $\begin{array}{c}\text { Grade 1Parallel } \\
\text { class }\end{array}$ \\
\hline
\end{tabular}

\subsection{Data collection}

In order to make my interview questions target my research questions, a pilot study was conducted to refine the research design before the interviews. Before my piloting study, I read kinds of literatures about online teaching, curriculum implementation then I drafted my first interview questions for my pilot study. The language used in these interviews is Chinese - the most familiar language for all participants. As the interviews aim to explore in-depth beliefs of teachers regarding their teaching online experience, thus full interactions and rapport hould be built with the most convenient language - our native language [2]. Then a semi-structured interview is conducted to explore participants' feelings and authentic understanding in a certain context towards the research topic.

\section{FINDINGS}

\subsection{Research questions}

Research Question: 1. What Factors May Affect Teacher's initiative in taking online English Class?

Research Question: 2. What are the Challenges Teachers have Encountered within Online Teaching?

\subsection{Findings to Research Question 1}

From the interview, only one participant did not attempt to use online tools. It is concluded that teachers' motivation of trying online classes can be affected by the following factors: teachers' personal life, peer pressure, and school policy.

One teacher among all the participants has the intrinsic motivation to teach students online. Unlike other factors, intrinsic initial makes a teacher enjoy the teaching process, so teachers with intrinsic motivation are more likely to present their students with the best class [15].

Additionally, the other four participants who have also taught online were affected by some external factors, such as school policy, colleagues' opinions, and leaders' expectations. However, participant E as a female teacher suffered a certain degree of teaching burnout for her family status and unsatisfactory reward. She said 'I think Ganjioayun offers a great class for students. Students can learn well if they put effort into the online course. Thus, I am not required to teach online, and I am not paid extra money for that. Additionally, my child is young, I want to give him as much company as I can.'

Apart from internal motivation. There are also external and internal factors that may make difference.

External factors include teaching training and supports. It is concluded from the research that external factors work together to affect teachers will of trying something challenging. Noticeably, $83 \%$ of participants got sufficient help from the school, colleagues and external resources. Most interestingly, comparing the performance between participants $\mathrm{E}$ and $\mathrm{F}$, it is found that financial aids play the most significant role in stimulating teachers to overcome challenges in teaching work instead of teaching experience.

In terms of internal factors, participants' school types, students' level and vocational training experience are considered crucial. Compared with participant E, D, F, the participant A got less exposed to educational technology because participants was trained and taught in the late 90s hen digital education had not emerged in Chinese classrooms yet. For participant B, D, it was their school types and student's types contributed to their flexible teachers' belief. They are teaching in the key high schools and key classes which means their schools are more resourceful, supportive. Moreover, their students are more spontaneous and self-motivated. Likewise, participant $\mathrm{A}$ is teaching the third grade in a normal senior high school, while she is teaching the top class which means much stress and workload in this duty, as participant $\mathrm{A}$ is preparing students to take the coming Gaokao exam. The significance of her role develops her adaptive teaching belief and makes her the most motivative teacher in online teaching among all the participants. 


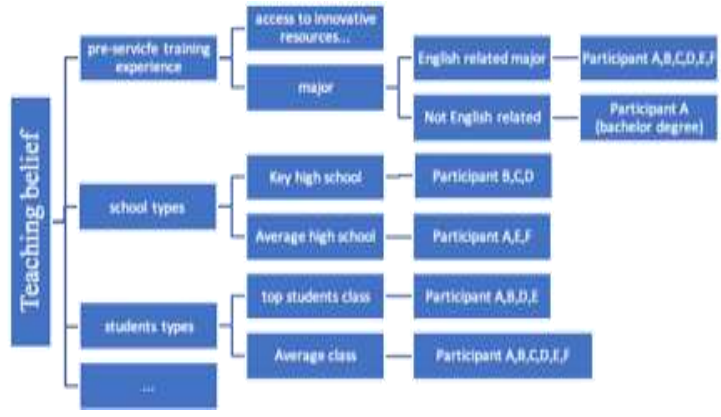

Figure 1 Factors that affect participants' teaching belief

\subsection{Findings to Research Question 2}

\subsubsection{Challenge 1: Changes in Syllabus}

Some changes took place in the online curriculum. Apart from the original objectives written on the national syllabus, the objective of the online class requires teachers to offer some supplementary support based on Ganjiaoyun online class.

The teaching methodology became more grammar-translation oriented because of the class platform limitation. Participants complained that Ganjiaoyun was not functional enough to create an interactive class thus even the reading class- which was more task-based were teacher-centred. Hence it made both teachers and students unsatisfied.

Students' needs analysis became more unachievable for teachers because teachers are not able to acquire immediate feedback from students. When they take physical class, teachers will get feedback from their observation such as students' homework, performance in class, and students' facial expression. Whereas distance teaching prevents teachers acknowledging how much students learned from Ganjiaoyun's class. Consequently, students' need analysis tends to be harder to obtain.

Compared with physical class, the form of assessment decreased dramatically. For example, dictation was cancelled, quiz, monthly quiz, mid-term/final exams were eliminated. Participant D complained that their students' vocabulary spelling skills have noticeably decreased due to a lack of dictation practice. Teachers chose to not implement these assessments because of students' low self-control ability. All participants found out some students were managed to cheat on the assessments or did not take the assessments seriously, thus teachers realized the feedback from these assessments was not reliable for student analysis. Based on the assessment, we can conclude that means and sources of evaluation have been simplified. Thus, the evaluation process became less time-consuming for most of the participants.

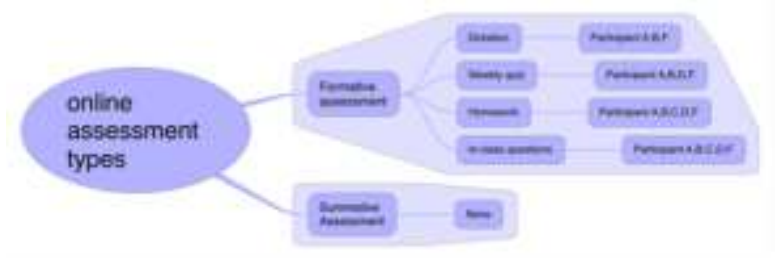

Figure 2 Types of assessments

\subsubsection{Challenge 2: Online Class Increased Teachers' Workload}

There are two main types of extra work these teachers had to deal with facing nline classes. The first challenge is a more complicated process of collecting and checking students' homework. Teachers had to spend extra time exploring new apps that can help collect students' homework. Moreover, students' homework is usually submitted in the form of pictures via Wechat application, which results in teacher's extra working time spent in checking photos in bad quality and urging delayed submission. The second time-consuming mission for teachers is to deal with after-school affairs, such as comforting anxious parents who do not believe in online learning, because students are unapproachable and less spontaneous without teachers' presences.

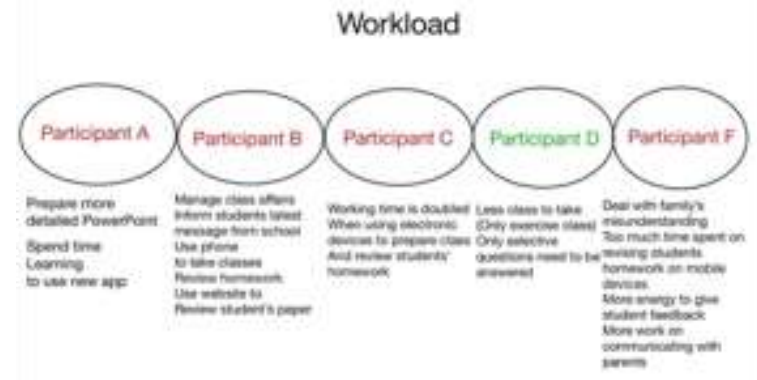

Figure 3 Participants' workload

\subsubsection{Challenge 3: Students 'Lack of Learning Motivation and Supervision}

According to participants' responses, it is concluded that the biggest challenge in online teaching was maintaining students' learning motivation and following up on students' learning progress. Every single participant mentioned that students always began with passion in the initial phase of online learning, however, students were easy to get bored with the teacher-centred teaching mode. Some students even stopped attending or faked being presentby using some tricks. Participant D and F suggested that Ganjiaoyun is dull and monotonous which demotivate students to focus on study. Students also found it was hard to concentrate on the online class itself because they could not interact with teachers. Participants A, B, C added that students were weak in self-discipline, they had problems in concentrating on studying without teachers' supervision so they can easily get tired. 


\subsubsection{Challenge 4: Health Problem and Technical Issues}

6 participants all showed their concerns about their health conditions. Participants A, C, D, F claimed that their eyesight had been hurt because of overusing digital devices during the online teaching period. Participant $\mathrm{C}$ felt the ache in phalangeal joints after 7-hour working in front of a computer.

Participant $\mathrm{F}$ also found she had some technical problems as she was teaching in a relatively remote countryside where the internet connection was bad. Therefore, her online class was always interrupted by bad connection, for example, sometimes students cannot see her or even hear her 'it was quite annoying' she complained.

\section{CONCLUSION}

Due to the Covid-19 pandemic, schools were forced to open online. The result of the national online learning is not as ideal as expected overall.

Teachers from different schools and varied backgrounds have different levels of motivation to conduct an online teaching mission. Their teaching belief is the main factor. Moreover, teachers encountered challenges from 4 perspectives which contributed to the undesirable learning outcomes.

Hopefully, more professional apps can be produced and introduced to Chinese teachers so that teachers can fulfil their regular teaching steps without concerning about any step that is unachievable by the current app. Moreover, more functional online tools can be introduced to teachers so teachers can make their teaching more efficient and flexible. For example, online dictations can be possible under teachers' supervision via cameras. Learning blogs can be created after class in the form of homework and students can be more interested. Therefore, teachers and students as well as parents should get more supports and trainings where they can update their ability to use the latest online teaching tools.

\section{REFERENCES}

[1] Bates, T., 2005. Technology, e-learning and distance education Second., London; New York: Routledge.

[2] De Jonckheere, M. \& Vaughn, L.M., 2019. Semistructured interviewing in primary care research: a balance of relationship and rigour. Family Medicine and Community Health, 7(2), p.e000057.

[3] Felix, U., 2005. E-learning pedagogy in the third millennium: the need for combining social and cognitive constructivist approaches. ReCALL, 17(1), pp.85-100.
[4] Firat, M., Kılınç, H. \& Yüzer, T.V., 2018. Level of intrinsic motivation of distance education students in e - learning environments. Journal of Computer Assisted Learning, 34(1), pp.63-70.

[5] Hepp, P., Fernández, M. \& García, J., 2015. Teacher training: technology helping to develop an innovative and reflective professional profile. RUSC, 12(2), pp.30-43.

[6] Hu, Yuhua, 2007. Chinese learners and computer assisted language learning: a study of learning styles, learner attitudes and the effectiveness of CALL in Chinese higher education.

[7] Kagan, D., 1992. Implications of Research on Teacher Belief. Educational Psychologist, 27(1), pp.65-90.

[8] Kaufman, D. (1989) 'Third generation course design in distance education', in Sweet,R. (ed.) Post-Secondary Distance Education in Canada: Policies, Practices and Priorities, Athabasca: Athabasca University/ Canadian Society for Studies in Education.

[9] MASLACH, C., JACKSON, S. E., \& LEITER, M. P. (1996). Maslach burnout inventory manual. Palo Alto, Calif. (577 College Ave., Palo Alto 94306), Consulting Psychologists Press.

[10] McCloskey et al., 2008. Developing English Language Curriculum for Online Delivery. CALICO Journal, 26(1), pp.182-203.

[11] Nipper, S. (1989). 'Third generation distance learning and computer conferencing', in Mason, R. and Kaye, A. (eds) Mindweave: Communication, Computers and Distance Education,Oxford: Pergamon.

[12] Ou Ming, 2010. A Research on Middle School Teachers' Application and Attitude towards Educational Technology Skills. Theory Studies. Internet Fortune, 173(20), pp. 187-190.

[13] Son, J.-B., 2018. Teacher Development in Technology-Enhanced Language Teaching 1st ed. 2018., Cham: Springer International Publishing: Imprint: Palgrave Macmillan.

[14] Wang, H., 2006. An implementation study of the English as a foreign language curriculum policies in the Chinese tertiary context, pp.ProQuest Dissertations and Theses.

[15] Wilkesmann, U. \& J. Schmid, C., 2014. Intrinsic and internalized modes of teaching motivation. Evidence-based HRM: a Global Forum for Empirical Scholarship, 2(1), pp.6-27.

[16] Yong, Z. \& Yue, Y., 2007. Causes for Burnout Among Secondary and Elementary School Teachers and Preventive Strategies. Chinese Education \& Society, 40(5), pp.78-85. 